\title{
DRUG ADDICTION: SELF-PERCEPTION OF ORAL HEALTH
}

\author{
Drogadição: Autopercepção em Saúde Bucal \\ Adicción a las drogas: auto percepción de la salud bucal
}

Original Article

\begin{abstract}
Objective: To report the self-perception of substance-abusing individuals who were in a recovery process regarding sociodemographic conditions and general and oral health. Methods: Descriptive cross-sectional study conducted in a recovery center for drug addiction in Alfenas, Minas Gerais, Brazil, in 2015, with 39 men aged over 18 years old. Data were collected using a semi-structured questionnaire that addressed: socioeconomic status, selfperception of general and oral health, access to dental care, relationship with the dentist, and other issues. In order to assess the self-perception of oral health, the variable was dichotomized into "satisfactory" and "unsatisfactory", which refer to what the individual acknowledges as a good or poor condition of oral health, using Fisher's exact test with 5\% significance level. Results: Most frequent diseases were depression, 35.90\% $(n=14)$, insomnia, $35.9 \%,(n=14)$ and recurring headache $(23.1 \% ; n=9)$; however, $61.50 \%(n=24)$ of the participants reported not getting sick easily, which contrasts with their self-perception. Regarding oral health, only $30.50 \%(n=12)$ of the participants reported brushing their teeth three times a day; $53.80 \%$ $(n=21)$ had dentinal hypersensitivity; $41.00 \%(n=16)$ had dry mouth and bad breath; $30.80 \%$ $(n=12)$ claimed to have bruxism and reported having one or more loose teeth; $28.20 \%(n=11)$ reported clenching the teeth in an exaggerated way, and $33.30 \%(n=13)$ reported feeling tooth pain. Conclusion: The self-perception of individuals - under 30 years old, single, white or mulattos - regarding their general health was contradictory, as they rated it as good but have reported depression, insomnia and weight loss; additionally, oral health was considered poor with unsatisfactory conditions, which highlights the harmful effects of substance abuse.
\end{abstract}

Descriptors: Quality of Life; Oral Health; Drug Users.

\section{RESUMO}

Objetivos: Relatar a autopercepção de indivíduos drogaditos que se encontravam em estágio recuperatório, quanto às condições sociodemográficas, de saúde geral e bucal. Métodos: Estudo descritivo e transversal realizado em 2015 em um centro de triagem de recuperação de dependentes químicos, em Alfenas, MG, Brasil, com 39 internos do sexo masculino e acima de 18 anos. Por meio de um questionário semi-estruturado, investigaram-se temas referentes à condição socioeconômica, percepção dos internos em relação à própria saúde geral e bucal, acesso ao tratamento odontológico, relacionamento com o cirurgião-dentista, entre outros. A variável autopercepção em saúde bucal foi dicotomizada em "satisfatória" $e$ "insatisfatória” para aplicação do teste Exato de Fisher, com nível de significância de 5\%. Resultados: As doenças mais frequentes foram depressão, 35,90\% (n=14), insônia, 35,9\%, $(n=14)$ e dor de cabeça recorrente $(23,1 \% ; n=9)$, apesar de $61,50 \%(n=24)$ dos internos afirmarem não ficar doentes, indicando autopercepção conflitante. Ao serem questionados sobre a frequência de escovação diária, apenas 30,50\% $(n=12)$ mencionaram três vezes ao dia, 53,80\% (n=21) com sensibilidade dentinária; 41,00\% $(n=16)$ com sensação de boca seca e mal hálito; 30,80\% (n=12) bruxismo, 28,20\% (n=11) apertamento dental e 33,30\% $(n=13)$ dor em algum dente. Conclusão: A autopercepção dos internos analisados com menos de 30 anos, solteiros, brancos ou mulatos, quanto ao seu estado geral de saúde era contraditória, já que classificaram como boa, mas relataram depressão, insônia e perda de peso; e saúde bucal foi considerada ruim com condições insatisfatórias, que destacam os efeitos nocivos do uso de drogas.

Descritores: Qualidade de Vida; Saúde Bucal; Usuários de Drogas.
Bianca Fernanda Espósito Santos $^{(1)}$

Eduardo Luiz Da-ré(1) Gabriel Ferreira Bello ${ }^{(1)}$ Gabriela Pereira Silva ${ }^{(1)}$

Leandro Araújo Fernandes ${ }^{(1)}$

Daniela Coelho de Lima ${ }^{(1)}$
Federal University of Alfenas Universidade Federal de Alfenas UNIFAL) - Alfenas (MG) - Brazil 


\section{RESUMEN}

Objetivo: Relatar la auto percepción de individuos drogadictos que estaban en proceso de recuperación, respecto las condiciones socio-demográficas y la salud general y bucal. Métodos: Estudio transversal y descriptivo realizado en un centro de recuperación para drogadicción en Alfenas, Minas Gerais, Brasil, en 2015, con 39 hombres con más de 18 años. Los datos fueron recogidos a través de un cuestionario semiestructurado que investigaba la posición socioeconómica, la auto percepción de la salud general y bucal, el acceso al cuidado dental, la relación con el dentista y otros temas. Para evaluar la auto percepción de la salud bucal la variable fue dividida en "satisfactoria" y "no satisfactoria" la cual refiere a los conocimientos del individuo sobre la buena o mala condición de salud bucal utilizando la prueba de Exacto de Fisher con el 5\% de nivel de significancia. Resultados: Las enfermedades más frecuentes fueron la depresión con el 35,90\% $(n=14)$, el insomnio con el 35,9\%, $(n=14)$ y dolor de cabeza recurrente $(23,1 \% ; n=9)$; sin embargo, el $61,50 \%(n=24)$ de los participantes relataron no enfermarse con facilidad lo que contrasta con su auto percepción. Respecto a la salud bucal, solamente el 30,50\% (n=12) de los participantes relataron cepillar los dientes tres veces al dia; el $53,80 \%$ (n=21) tuvieron hipersensibilidad dental; el 41,00\% $(n=16)$ tuvieron la sensación de boca seca y mal aliento; el $30,80 \%(n=12)$ reclamaron de bruxismo y relataron tener uno $o$ más dientes perdidos; el 28,20\% $(n=11)$ relataron apretar los dientes de manera exagerada y el 33,30\% $(n=13)$ relataron tener dolor de diente. Conclusión: La auto percepción de los individuos - por abajo de los 30 años, solteros, blancos o mulatos - respecto su salud general fue contradictoria ya que clasificaron como buena aunque reportaron la depresión, el insomnio y la pérdida de peso; además, la salud bucal fue considerada pobre con condiciones no satisfactorias, las cuales resalta los efectos nocivos de la substancia abusiva.

Descriptores: Calidad de Vida; Salud Bucal; Consumidores de Drogas.

\section{INTRODUCTION}

According to the World Health Organization (WHO) $)^{(1)}$, substance-related disorders are any mental and behavioral disorders induced by drug abuse - the term "drug addiction", also known as substance abuse, was created to define any and all biochemical addictions an individual may present to a drug; in addition, the term is used to refer to the chemical causes related to social, economic, political, and genetic inclusion and/or exclusion ${ }^{(1)}$.

Psychoactive substance abuse has been considered a major public health problem given the fact that it causes undesirable damage that has a social, cultural and economic impact and affects the health of individuals ${ }^{(2)}$. Given that, Brazil's government, in line with the social movement, is striving to raise awareness of the importance of health actions and measures to minimize the adverse consequences of the harmful use of alcohol and drugs ${ }^{(3)}$.

An approach by a multidisciplinary team composed of professionals from various fields gives rise to multiple intervention strategies in an attempt to neutralize the harmful effects of chemical dependency, increasing the success in the treatment of this population ${ }^{(4)}$.

Such approach is of utmost importance, as drugs like alcohol, tobacco, marijuana, cocaine and crack cocaine, among others, destroy reputation, jeopardize real sense, weaken or take away one's sense of responsibility, and destroy the family and the individual him/herself, who suffers many physical, chemical and emotional changes ${ }^{(5)}$. Therefore, oral health becomes poor and suffers many changes ${ }^{(6)}$ due to direct effects on oral structures (mucosa, teeth, tongue), including leucoplakias and carcinomas ${ }^{(7)}$.

Because of the increasing number of substance-abusing people, Dentistry needed to expand its field in order to treat such patients ${ }^{(8)}$. This was made possible by knowing the clinical oral health profile of these people in order to avoid complications such as prescribing and administering systemic medication that may cause undesirable drug interactions, even when the patient does not report substance abuse during anamnesis ${ }^{(3)}$.

Other indicators are breath odors, increased volume of the parotid glands, high blood pressure, tachycardia and cancerous lesions. For alcoholic patients, acid drugs such as aspirin and Nonsteroidal Anti-inflammatory Drugs (NSAIDs) must be avoided as they may cause gastrointestinal bleeding. Furthermore, an absolute interaction between vasoconstrictor drugs and cocaine may occur, prohibiting the use of the two drugs together ${ }^{(9)}$.

In addition, oral health promotion is part of a broad concept of health that must transcend the purely technical dimension of the dental industry, integrating it to other public health practices ${ }^{(10)}$.

Moreover, it should be noted that Dentistry can relieve pain and also contribute to the psychosocial rehabilitation of substance-abusing individuals, helping in the development of self-esteem and in the improvement of social interaction, since recovery involves redemption of the human being in all aspects ${ }^{(3)}$. Besides, the individual who is in a recovery process must be fully treated by integrating medical and psychiatric care to an educational approach - in order to improve oral health - and to a rehabilitative care to maintain the integrity of oral structures ${ }^{(7)}$.

Thus, perception, which is the ability of perceiving something, should be encouraged within this population because it develops a perception through which the individual sees him/herself in relation to his health condition, which drives them to achieve a better quality of life ${ }^{(1)}$. 
Therefore, the aim of this study was to report the selfperception of substance-abusing individuals who were in a recovery process regarding sociodemographic conditions and general and oral health.

\section{METHODS}

This is a descriptive cross-sectional study conducted between January and November 2015 to report the health conditions of individuals admitted to a recovery center for drug addiction - Grupo Arco-íris de Misericórdia in Alfenas, Minas Gerais (Rainbows of Mercy Group). Inclusion criteria were men over 18 years old admitted to the center who agreed to participate in the research. As their stay was temporary, the sample comprised 39 participants. Individuals who left the center for any reason were excluded from the study.

Data were collected using a survey form ${ }^{(11)}$ composed of open- and closed-ended questions in order to obtain a greater results coverage.

Due to the special characteristic of the study population, the questionnaire was applied individually in the reception room of the center. Data were collected by a single trained researcher in order to avoid any interference with or manipulation of the records; the researcher read the questions and answer options and wrote down the answers given by the participants. The average time spent on the application of this instrument was 20 minutes, and it was hand-written by the researcher.

There was also the possibility of the respondent to refuse to answer any questions for any reason. The questionnaires were stored in a file folder together with other questionnaires in order to prevent the identification of the individual and ensure the confidentiality of information - the questionnaires did not contain personally identifiable information.

The questionnaires addressed issues such as socioeconomic status, self-perception of oral health, access to dental care, relationship with the dentist, among others. These variables were analyzed through a descriptive analysis of the percentage of responses. Studies on selfperception of oral health comparing the patient's selfreport to clinical data are important because they analyze the reliability and validity of the results and are essential in obtaining information quality ${ }^{(12)}$.

The data obtained were tabulated using EpiInfo 6.2.2, which generated an information database; data underwent descriptive statistics and the correlation between variables was verified using Fisher's exact test with a significance level of $p \leq 0.05$ and a $95 \%$ confidence interval.
The research was approved by the Human Research Ethics Committee of the Universidade Federal de Alfenas (Federal University of Alfenas) in Minas Gerais (Opinion No. 218/2011) and data collection was carried out in 2015. As part of the documentation required by law, a free and informed consent form - in plain language - was handed to explain the purposes of the study, procedures, risks, discomfort and benefits, the guarantee of anonymity and the declaration of consent. In addition, the research was authorized through the written consent from the director of the institution.

\section{RESULTS}

Regarding the personal characteristics of participants, $66.70 \%(n=26)$ were under 30 years old, $76.90 \%(n=30)$ were single, $77.00 \%(\mathrm{n}=30)$ were white or mulattos, and $41.00 \%(n=16)$ did not conclude elementary school.

With regard to the reason that led to substance use, most respondents reported curiosity, $38.50 \%(n=15)$ of the answers, followed by group influence, $35.90 \%(\mathrm{n}=14)$, family problems $23.10 \%(\mathrm{n}=9)$, and other factors like drug trafficking, recreational use, end of a relationship, kind of job done by parents and imprisonment.

The most used substances were alcohol, $92.30 \%$ $(\mathrm{n}=36) ; \quad$ marijuana, $82.10 \% \quad(\mathrm{n}=32) ;$ tobacco, $79.50 \%$ $(n=31)$; cocaine $71.80 \% \quad(n=28)$; and crack cocaine $69.20 \%(\mathrm{n}=27)$. When participants reported using "other substances", the most reported option was solvents, $38.50 \%$ $(\mathrm{n}=15)$. Preferred substances were crack cocaine, $43.60 \%$ $(\mathrm{n}=17)$; alcohol, $23.10 \%(\mathrm{n}=9)$; and cocaine, $12.80 \%(\mathrm{n}=5)$.

There was a wide range of lifetime substance abuse. Some participants reported having used substances from one up to thirty-nine years in a lifetime; the most significant ranges were 1 year, 14 years and 20 years $(10.30 \% ; n=4$, for all of them).

With regard to information obtained about drugs, $41.00 \%(n=16)$ of the interviewees reported they have obtained information at school but have ignored them.

It was observed that $66.70 \%(n=26)$ of the participants do not make frequent use of medication. Among those who use any kind of medication, $53.90 \%(n=21)$ use benzodiazepines like Diazepan $\AA$ and Rivotril ${ }^{\circledR}$ and $15.40 \%$ $(n=6)$ use barbiturates like Gardenal ${ }^{\circledR}$ and phenytoin.

Most frequent diseases were depression, $35.90 \%$ $(\mathrm{n}=14)$, insomnia, 35.9\%, $(\mathrm{n}=14)$ and recurring headache $(23.1 \% ; n=9)$. Regarding allergic reactions, $92.3 \%(n=36)$ reported no anaphylactic reaction.

Among the interviewees, $94.90 \%(n=37)$ denied any eating disorders and $89.70 \%(n=35)$ did not report 
taste disorders. During the period of substance drug, most participants, $97.30 \%(\mathrm{n}=38)$, lost weight.

When asked about general health, 61.50\% ( $\mathrm{n}=24)$ of the participants reported not getting sick easily, which contrasts with the self-perception of lack of personal care. The respondents experienced more hallucination episodes - $59.00 \%(\mathrm{n}=23)$ of the cases - than convulsion $-23.10 \%$ $(n=9)$. Only $12.80 \%(n=5)$ of the participants reported medical negligence.
Table I shows the reasons that motivated the individual to go to the dentist; the need for tooth extraction, $20.50 \%$ $(\mathrm{n}=8)$, and pain symptoms, $20.50 \%(\mathrm{n}=8)$ were the most common reasons. In all, $61.50 \%(\mathrm{n}=24)$ of respondents started dental treatment, but for some reason it has not been concluded. In the present study, the most frequently reported reasons for not completing the treatment were sloppiness, $45.50 \%(\mathrm{n}=18)$, and lack of money, $18.20 \%(\mathrm{n}=7)$.

Table I - Reason for the last dental appointment. Alfenas, Minas Gerais, 2015.

\begin{tabular}{lcc}
\hline Problems & n & \% \\
\hline Cavity & 3 & 7.70 \\
Pain & 8 & 20.50 \\
Aesthetics & 2 & 5.10 \\
Routine & 3 & 7.70 \\
Maintenance of braces & 1 & 2.60 \\
Gum Problems & 1 & 2.60 \\
Extraction & 8 & 20.50 \\
Endodontics & 3 & 7.70 \\
Other & 10 & 25.60 \\
\hline Total & 39 & 100.00 \\
\hline
\end{tabular}

The majority of the population, $97.40 \%(\mathrm{n}=38)$, say the teeth are important, and when asked about the reason for the dental visit, $86.60 \%(n=34)$ reported aesthetics and/or appearance as relevant factors.
Regarding the self-perception of dental condition, only $7.7 \%(\mathrm{n}=3)$ of the participants rated their teeth as poor; however, as for oral health, $20.5 \%(\mathrm{n}=8)$ rated it as poor (Table II).

Table II - Self-perception of dental condition and oral health. Alfenas, Minas Gerais, 2015.

\begin{tabular}{|c|c|c|c|c|c|c|c|c|c|c|c|c|}
\hline \multirow{2}{*}{ Self-perception } & \multicolumn{2}{|c|}{ Very Poor } & \multicolumn{2}{|c|}{ Poor } & \multicolumn{2}{|c|}{ Fair } & \multicolumn{2}{|c|}{ Good } & \multicolumn{2}{|c|}{ Very Good } & \multicolumn{2}{|c|}{ Total } \\
\hline & $\mathbf{n}$ & $\%$ & $\mathbf{n}$ & $\%$ & $\mathbf{n}$ & $\%$ & $\mathbf{n}$ & $\%$ & $\mathbf{n}$ & $\%$ & $\mathbf{n}$ & $\%$ \\
\hline $\begin{array}{l}\text { Perception of dental } \\
\text { condition }\end{array}$ & 6 & 15.40 & 3 & 7.70 & 18 & 46.20 & 11 & 28.20 & 1 & 2.60 & 39 & 100.00 \\
\hline Perception of oral health & 2 & 5.10 & 8 & 20.50 & 15 & 38.50 & 11 & 28.50 & 3 & 7.70 & 39 & 100.00 \\
\hline
\end{tabular}

Table III - Self-perception of the need for dental treatment. Alfenas, Minas Gerais, 2015.

\begin{tabular}{lcc}
\hline Perception & n & \% \\
\hline All treatments & 2 & 4.22 \\
Dental restoration & 8 & 21.10 \\
Cleaning & 6 & 14.10 \\
Orthodontics & 5 & 12.70 \\
Prosthesis & 4 & 11.30 \\
Extraction & 3 & 8.50 \\
Endodontics & 3 & 7.00 \\
Whitening & 2 & 5.60 \\
Periodontics & 2 & 4.20 \\
Pain & 1 & 2.80 \\
\hline Total & 39 & 100.00 \\
\hline
\end{tabular}


Table IV - Percentage distribution of the sample according to daily brushing, flossing and use of mouthwash. Alfenas, Minas Gerais, 2015.

\begin{tabular}{lcccccc}
\hline \multirow{2}{*}{ Variable } & \multicolumn{2}{c}{ Brushing } & \multicolumn{2}{c}{ Flossing } & \multicolumn{2}{c}{ Mouthwashing } \\
& $\mathbf{n}$ & $\mathbf{\%}$ & $\mathbf{n}$ & $\mathbf{\%}$ & $\mathbf{n}$ & $\mathbf{\%}$ \\
\hline No & 4 & 10.30 & 26 & 66.70 & 33 & 84.60 \\
Occasionally & 2 & 5.10 & 5 & 12.80 & 0 & 0.00 \\
Yes & 33 & 84.60 & 8 & 20.50 & 6 & 15.40 \\
Total & 39 & 100.00 & 39 & 100.00 & 39 & 100.00 \\
\hline
\end{tabular}

In the present study, $38.50 \%(\mathrm{n}=15)$ of the participants said they were satisfied with their oral health; however, $91.50 \%(\mathrm{n}=36)$ reported they need treatment and $21.10 \%$ $(n=8)$ needed restorative treatment (Table III).

With regard to the last visit to the dentist, $56.30 \%$ $(n=22)$ of respondents reported their last visit took place las than a year ago. In all, $30.80 \%(n=12)$ of the participants said they have omitted substance abuse during the dental treatment.

As for oral hygiene practices carried out by the participants, $84.60 \%(\mathrm{n}=33)$ perform tooth brushing, but only $20.50 \%(n=8)$ use dental floss and $15.40 \%(n=6)$ use mouthwash (Table IV).

In the present study, only $35.90 \%(n=14)$ of ex-drug users reported they have been counselled about the risks of drug use for dental treatment, and only $2.60 \%(n=1)$ were aware of the complications of the use of dental anesthesia.

Regarding the presence of periodontal disease, the majority, $66.7 \%(\mathrm{n}=26)$, reported no gum problems.

As for dental problems, $30.80 \%(\mathrm{n}=12)$ of respondents reported having one or more loose teeth, $33.30 \%(n=13)$ reported tooth pain - of these, $66.70 \%(\mathrm{n}=26)$ presented painful symptomatology when eating cold foods. In addition, $53.80 \%(\mathrm{n}=21)$ of respondents reported having dentinal hypersensitivity.

The following problems have also been reported: $41.00 \%(n=16)$ had dry mouth; $41.00 \%(n=16)$ felt bad taste in the mouth; $41.00 \%(\mathrm{n}=16)$ had bad breath; $30.80 \%$ $(\mathrm{n}=12)$ had bruxism; and $28.20 \%(\mathrm{n}=11)$ reported clenching the teeth in an exaggerated way.

During drug use, $66.70 \%(n=26)$ of respondents showed episodes of burns on the lips, oral mucosa and tongue. In addition, other types of injuries such as thrush $(30.80 \%$; $\mathrm{n}=12)$, abscesses $(15.40 \% ; \mathrm{n}=6)$ and herpes $(7.70 \% ; n=3)$ were also found.

\section{DISCUSSION}

The present study was conducted in a recovery center for drug addiction where patients stay for a relatively short time. Individuals were aged over 18 years. In all, 39 men participated effectively because some inmates were referred for definitive treatment of drug addiction while others quit the treatment. These results are consistent with another study on drug addiction ${ }^{(12)}$.

The study of self-perception favors the understanding of the oral health context in which people are inserted and provides ways to improve health education ${ }^{(13)}$. This is one of the purposes of the present study: to foster critical thinking through self-awareness so that the participants become aware of their oral condition in relation to substance abuse and hence develop habits and behaviors that contribute to a better health.

When an individual develops her/his self-perception, $\mathrm{s} /$ he stops acting only as a patient and becomes a diagnostician of her/his oral health condition, collaborating and actively participating in the maintenance of oral health ${ }^{(14)}$.

In the present study, curiosity was the most prevalent reason for trying drugs for the first time, followed by the influence of friends and family issues. In another study ${ }^{(15)}$, the main reasons for trying substances reported by adolescents were divided into: the pursuit of pleasure; curiosity; desire to have an experience; group influence and social pressure. During adulthood, drugs are usually used in an attempt to relieve problems, nervousness, insomnia or stress. In the present study, curiosity was the main reason for trying drugs, a finding that is in line with that of a study on early drug addiction ${ }^{(16)}$, which revealed that curiosity, family problems and friends' influence were significant predisposing factors.

The use of multiple substances is a characteristic of modern times that has gradually replaced the exclusive use $^{(10)}$. One of the various motivations for this contemporary pattern of substance use is the need to manipulate the intensity or the drug in an attempt to minimize the consequences of the withdrawal or enhance and prolong its effects ${ }^{(11)}$. For instance, there is the alcohol consumption after the abuse of crack cocaine with the intention of mitigating the negative effects of the withdrawal and also the concomitant use of marijuana and crack cocaine (mixed), which prolongs its $\operatorname{effect}^{(17)}$. In the present study, the respondents' most 
commonly used substances were alcohol, crack cocaine, marijuana, tobacco and cocaine - many of which were used concomitantly.

There was a wide range of lifetime substance abuse in the present study, with participants reporting the use of substances from one up to thirty-nine years in a lifetime. The same parameter was found in a study ${ }^{(18)}$ that related attitudes and behaviors of drug users to oral health.

The literature ${ }^{(19)}$ suggests the development of counseling and education programs in the various social sectors (schools, universities, communities, etc.) to prevent substance abuse and also detect and refer for treatment individuals with problems potentially-related to substance use and abuse. Respondents of the present study said they received information in the school environment for not using drugs; however, they ignored them.

The addiction process involves environmental, biological, psychological and pharmacological factors, and it appears to be closely associated with an increase of medical disorders, clinical problems and the social deterioration of the individual ${ }^{(20)}$.

The most prevalent diseases or medical conditions caused by substance abuse were psychosomatic disorders and weight loss, the latter being probably caused due to unhealthy eating habits. Additionally, participants presented severe degrees of various oral and dental diseases caused most of the times - by the neglect of health oral ${ }^{(13)}$.

With regard to general health, more than half of the participants reported not getting sick easily, revealing a distorted perception of reality, as they were careless with their personal care. This shows the drug user's lack of commitment to his own general health ${ }^{(21)}$. Regular visits to the dentists are difficult due to their lifestyle: they miss appointments and have difficulties affording the procedures $^{(19)}$.

With regard to oral health in general, worse ratings were given by the participants, although just a few rated their teeth conditions as poor. Another study ${ }^{(22)}$ found that $100 \%$ of hospitalized patients rated their oral health good.

It can be observed that drug users realize how miserable their oral health is when they are in periods of abstinence, and they often feel embarrassed or ashamed because of their appearance ${ }^{(23)}$.

A study conducted in 2011(5) found a negative correlation between the level of importance given to the teeth and the need for treatment - the greatest need for dental care is presented by those people who give less importance to oral health. In the present study, it was observed that this is due to a more precarious oral hygiene or because the respondents seek the dentist less often.
Substance-abusing individuals usually have a reduction/inhibition in the frequency of use of dental services due to the higher priority in obtaining drugs and the little concern for oral health, fear of dentists, acceptability of proposed treatments, needle phobia, easy self-medication and difficulties to find the time to go to the dentist at least once in life ${ }^{(13)}$. Some participants also felt that the fact that they are drug users makes it difficult to find professionals willing to treat them; additionally, they feel discriminated because they are usually scheduled for late hours and dentists usually use more than one glove ${ }^{(19)}$. In the present analysis, many participants reported they have omitted being drug users in order to receive treatment.

Therefore, it is essential that clinicians are aware of the numerous oral and dental manifestations caused by drugs in order to make correct diagnoses for an adequate treatment ${ }^{(24)}$.

Substance-abusing individuals have constant oral changes that will not disappear with the end of use $\mathrm{e}^{(6,7)}$. The most prevalent changes found in other studies are bruxism, dry mouth, halitosis, mobility caused by periodontal disease, bad taste in mouth, among others ${ }^{(6,5,10,25)}$. Despite the advances in Dentistry, and particularly in Periodontics, epidemiological studies ${ }^{(17,24)}$ have shown that periodontal disease still has a high prevalence in the population.

No association is reported between substance abuse and tooth hypersensitivity in the literature, but there may be an association between the low $\mathrm{pH}$ of most substances and a loss of tooth mineralization ${ }^{(26)}$.

Pain in substance-abusing individuals is usually masked by the analgesic effect of narcotics. As a result, they live with serious problems in the oral cavity ${ }^{(6)}$. Respondents in the present study reported burns on lips, oral mucosa and tongue during substance use. In addition, they also reported other types of injuries such as ulcers, abscesses and herpes.

Based on the overview of these individuals, the recovery centers for drug addiction usually have a referral system that refers individuals to other services to improve the systemic health ${ }^{(27)}$. Thus the dentists have to strive to participate in these networks, so that they can contribute to the fight against drugg ${ }^{(19)}$. This strategy emphasizes the drug users' need for adequate access to appropriate services, including primary care, which should support them to change their behavior in relation to healthier lifestyles ${ }^{(28)}$. This need was identified in the present study because all the participants reported that it would be important to have a dentist in the multidisciplinary team during the treatment of drug addiction, especially with regard to the counselling and treatment of hospitalized individuals.

Due to the neglect of oral health by the participants of the present study and complaints of oral hygiene problems, 
expository and demonstrative lectures on education and oral health were carried out, reinforcing the importance of proper brushing and effective flossing. The frequency of brushing usually recommended in the literature is two to three times a day, and there is consensus on the daily flossing ${ }^{(25)}$. During the lectures, the participants were warned about the major diseases of the oral cavity such as caries, gingivitis and periodontitis. In addition, they were informed about how a good hygiene can prevent them. Interviewees were interested in the subject and exposed their doubts, which were clarified in plain language in order to be easily understood. As part of the health education activities, participants were given an oral hygiene kit containing toothbrush, toothpaste and dental floss, encouraging them to put the information given into practice.

However, because it is a study of drug addiction, there are several limitations that should be highlighted. For instance, behavior changes and lack of tolerance during the period of abstinence and "craving" were observed; in addition, some participants showed signs of irritability, anguish, anxiety, psychomotor agitation, tiredness, general discomfort caused by muscle pain, and headache.

The health sector has a lot to accomplish concerning drug abuse and health promotion. The need to face drug addiction as a distinct reality that needs monitoring - and not only as a matter of moral or character of the individual - highlights the importance of discussing actions of health promotion and drug abuse prevention in order to reduce this phenomenon in the society ${ }^{(1,3,7)}$.

\section{CONCLUSION}

The self-perception of individuals - under 30 years old, single, white or mulattos - regarding their general health was contradictory, as they rated it as good but have reported depression, insomnia and weight loss; additionally, oral health was considered poor with unsatisfactory conditions, which highlights the harmful effects of substance abuse.

\section{REFERENCES}

1. World Health Organization. Mandate and activities to counter the world drug problem: a public health perspective. Genebra: WHO; 2014.

2. Andretta I, Oliveira MS. A entrevista motivacional em adolescentes usuários de droga que cometeram ato infracional. Psicologia: Reflexão e Crítica. 2011; 24(2):218-26.

3. Elias LA, Bastos FI. Saúde pública, redução de danos e a prevenção das infecções de transmissão sexual e sanguínea: revisão dos principais conceitos e sua implementação no Brasil Ciênc Saúde Coletiva. 2011;16(12):4721-30.

4. Chaves TV, Zila MS, Ribeiro LA, Nappo SA. Crack cocaine craving: behaviors and coping strategies among current and former users. Rev Saúde Pública 2011;45(6): 1168-75.

5. Mendonça NA, Silva CM, Venturini RT. Tratamento odontológico em pacientes usuários de drogas ilícitas: relato de caso clínico. In: Anais da XIV Jornada Acadêmica De Odontologia Da Universidade Do Oeste Paulista, São Paulo, 2011 Maio 4-6. Presidente Prudente: Faculdade de Odontologia UNOESTE. p. 26.

6. Gabardo MCL, Moysés ST, Moysés S. Autopercepção de saúde bucal conforme o Perfil de Impacto da Saúde Bucal (OHIP) e fatores associados: revisão sistemática. Rev Panam Salud Publica. 2013;33(6):439-45.

7. Costa SKP, Godoy GP, Gomes DQ, Pereira JV, Lins RDAU. Fatores sociodemográficos e condições de saúde bucal em droga-dependentes. Pesqui Bras Odontopediatria Clín Integr. 2011;11(1):99-104.

8. Pereira EDB, Freitas EPP, Moreira BA, Paula FA, Santos RDP, Matos AGC. Impact of smoking on oral health of patients attending at outpatient medical clinic. Rev Bras Promoç Saúde. 2014;27(1):37-42.

9. Vieira APGF, Saintrain MVDL. Reflexões sobre a Saúde bucal no Brasil. Rev Bras Promoç Saúde. 2013,26(4):451-2.

10. Capistrano FC, Ferreira ACZ, Maftum MA, Kalinke LP, Mantovani MF. Impacto social do uso abusivo de drogas para dependentes químicos registrados em prontuários. Cogitare Enferm. 2013;18(3):468-74.

11. Garcia EL, Zacharias DG, Winter GF, Sontag J. (Re) conhecendo o perfil do usuário de crack. Revista Barbarói. 2012;36:83-95.

12. Baran MF, Parizotto APAV, Rossi ML. Concepções dos usuários de crack sobre os motivos que levaram ao consumo. Convibra Saúde, 2012. [acessed on 2014 Nov 08]. Available from: www.convibra.com.br/ upload/paper/2012/59/2012_59_4305.pdf

13. Cassol PB, Terra MG, Mostardeiro SCTS, Gonçalves MO, Pinheiro UMS. Tratamento em um grupo operativo em saúde: percepção dos usuários de álcool e outras drogas. Rev Gaúcha Enferm. 2012;33(1):132-8.

14. Floriano F, Mda CC, Sheiham A, Tsakos G, Vianna MI, Cabral MB. Relationship between clinical dental status and the perception of oral health-related quality of life in adults. Brazil. J Epidemiol Community Health. 2011;6(31):A431. 
15. Sanchez ZVM, Oliveira LG, Ribeiro LA, Nappo SA. O papel da informação como medida preventiva ao uso de drogas entre jovens em situação de risco. Ciênc Saúde Coletiva. 2010;15(3):699-708.

16. Nemesio DA. Uso de álcooll, tabaco e drogas por jovens e adultos da cidade de Recife. Psicol Argum. 2011;29(66):295-302.

17. Damante CA, Greghi SLA, Rezende MLR, Sant' Ana ACP, Passanezi E. Efeitos das drogas ilícitas em saúde periodontal e bucal. Perionews. 2011;5(3):251-55.

18. Santos JDP, Silveira DV, Oliveira DF, Caiaffa WT. Instruments used to evaluate smoking habits: a systematic review. Ciênc Saúde Coletiva. 2011;16(12):4707-20.

19. Lima DC, Saliba NA, Garbin AJI, Fernandes LA, Garbin CAS. A importância da saúde bucal na ótica de pacientes hospitalizados. Ciênc Saúde Coletiva. 2011;16(Supl1):1173-80.

20. Riva R, Rotemberg E, Sanguinetti M, Rodríguez A, Massa F. Drug Dependence, Bruxism and Temporomandibular Disorders. Comparative analysis of two populations: nationwide sample and Portal Amarillo's population in treatment for problematic drug use. Odontoestomatología. 2014;15(24):26-33.

21. BrennanDS, SpencerAJ. Dental visiting history between ages 13 and 30 years and oral health related impact. Community Dent Oral Epidemiol.2014;42(3):254-62

22. United Nations Office On Drugs and Crime. World drug report 2012. Geneva; 2012.
23. Departamentod Health and Human Service (US). The National Institute on Drug Abuse: understanding drug abuse and addiction. Washington: HHS; 2011.

24. Lopes MWF, Gusmão ES, Alves RV, Cimões R. Impacto das doenças periodontais na qualidade devida. RGO (Porto Alegre). 2011;59(Supl):39-44.

25. Oliveira BA, Biazevic MGH, Michel-Crosato E. Prevalência de dor de dente, cárie dental e condições sócio-econômicas: um estudo em adultos jovens brasileiros. Odonto. 2011;19(38):7-14.

26. Gigena PC, Bella MI, Cornejo LS. Salud bucal y hábitos de consumo de sustâncias psicoactivas en drogodependientes en recuperación. Odontoestomatol. 2012;14(20): 49-5.

27. Kusma SZ, Moysés ST, Moysés SJ. Promoção da saúde: perspectivas avaliativas para a saúde bucal na atenção. Cad Saúde Pública. 2012;28(Supl):9-19.

28. Gabatz RIB, Schmidt AL, Terra MG, Padoin SMM, Silva AA, Lacchini AJB. Percepção dos usuários de crack em relação ao uso e tratamento. Rev Gaúcha Enferm. 2013;34(1):140-46.

\section{Mailing address:}

Bianca Fernanda Espósito Santos

Universidade Federal de Alfenas

Rua Gabriel Monteiro da Silva, 700

Bairro: Centro

CEP: 37130000 - Alfenas - MG - Brasil

E-mail: biancaferr_esposito@hotmail.com 